
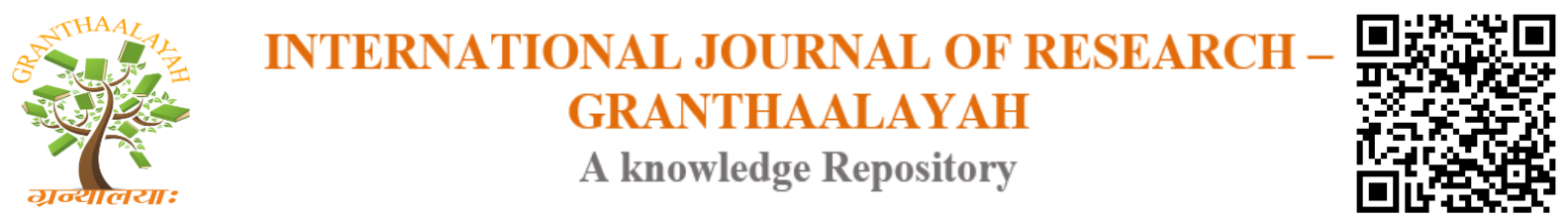

Management

\title{
A STUDY ON CHALLENGES, OPPORTUNITY AND POVERTY REDUCTION THROUGH MICRO FINANCE IN INDIA
}

\author{
R. Shankar ${ }^{* 1}$, Dr. N. Senthilkumar ${ }^{2}$ \\ ${ }^{* 1}$ Ph.D., Research Scholar, Kandaswami Kandar's College, P-Velur, Namakkal, INDIA \\ ${ }^{2}$ Assistant Professor \& Research Supervisor, PG \& Research Department of Commerce, \\ Kandaswami Kandar's College, P-Velur, Namakkal, INDIA
}

DOI: https://doi.org/10.29121/granthaalayah.v4.i10(SE).2016.2468

\begin{abstract}
Poverty is a term with which manly developing countries are suffering. The poor people one of basic need for financial requirements to socio economic developments. Micro-finance has become one of the most effective interventions for economic empowerment of the poor. The experience across India and other countries has shown a robust potential of Microfinance to integrate with the development issues thereby significantly impacting the lives of poor. In this research paper indicates that role micro finance large contribution to economic development of poor people as well as challenges, opportunity and poverty reduction through micro finance.

Keywords:

Poverty reduction, Microfinance, Past Poverty Reduction Initiatives, Mahalir hittam.

Cite This Article: R. Shankar, and Dr. N. Senthilkumar, "A STUDY ON CHALLENGES, OPPORTUNITY AND POVERTY REDUCTION THROUGH MICRO FINANCE IN INDIA" International Journal of Research - Granthaalayah, Vol. 4, No. 10: SE (2016): 50-56.
\end{abstract}

\section{INTRODUCTION}

Poverty is a term with which manly developing countries are suffering. The financial requirement is one of the basic needs of the poor section of the society for socio-economic development. Most of people are living in India below poverty line and finance to these indigenous people is considered as important issues for the poverty for the Government of India. Microfinance to Self Help Groups (SHGs) may be considered as a vital option for meeting the financial needs of those poorer sections of the society. Microfinance is the form of financial development that has its primary aim to alleviate the poverty. Governments, donors and NGOs around the world responded enthusiastically with plans and promised to work together towards the realization of these goals. 
The Government of India and various state Governments have been implementing various programmes for rural upliftment. However, rural poverty and unemployment still persist in the country. This problem is becoming severe and acute. The available latest statistics relating to the Indian Economy indicates that about $26 \%$ of the total population in the country belongs to the rural poor.

Considering the gravity and intensity of the problem, many Voluntary Development Organisations (VDOs) have come forward with different programmes for the rural poor in the country. These agencies undertake various innovative programmes and schemes to address the issues of poverty and unemployment prevailing in our country.

Among the various programmes "Swarna Jayanti Grama Swarojgar Yojana" (SGSY) is an important one. This programme was launched on 1st April, 1999, at 75: 25 costs sharing between Central and State Governments.

The main objective of this programme is to bring the beneficiaries above the poverty line by providing income generating assets to them through bank credit and government subsidy. The Self-Help Groups (SHPs) are the major component of this scheme.

Women are a vital part of the Indian Economy, both at the national and the household levels. They make one-third of the national labour force. Compared with their menfolk, Indian women contribute a much larger share of their earnings to basic family maintenance with the result that women's earnings positively and immediately affect the incidence and the security of poverty.

Microfinance has proven to be an effective and powerful tool for poverty reduction. Like many other development tools, however, it has insufficiently penetrated the poorer strata of society. The poorest form the vast majority of those without access to primary health care and basic education; similarly, they are the majority of those without access to microfinance. While there is no question that the poorest can benefit from primary health care and from basic education, it is not as intuitive that they can also benefit from microfinance, or that microfinance is an appropriate tool by which to reach the Millennium goals.

\section{OBJECTIVE OF STUDY}

- To study the impact of SHGs on the rural people.

- To find challenges and opportunity to SHGs through micro finance.

- To study the socio-economic level of SHGs group.

\section{LIMITATION OF STUDY}

- To this research study for selected district only.

- To most of respondents are a woman's related to SHGs.

- To use analysis data only percentage method. 


\section{REVIEW OF LITERATURE}

M. Anjugam (2007) observed that socially backward, landless and marginal farm house holds participate more in the self-help group programme. Possession of livestock and consumer goods by the member households has been found to deter the joining of group.

Gladis Mary John (2008) found that membership in SHG inculcated a great confidence in the mind of majority of women to succeed in day to day life. Positive change was found in the attitude of relatives and friends towards the women in self-help groups.

\section{PAST POVERTY REDUCTION INITIATIVES}

Government of Tamil Nadu (GoTN) has been implementing various centrally sponsored schemes for poverty reduction like Sampoorna Grama Rozgar Yojana, Indra Awaas Yojana, Innovative stream for Rural Housing and Habitat Development, Pradhan Mantri Gramodaya Yojana, Pradhan Mantri Sadak Yojana, Swarna Jayanthi Gram Swarozgar Yojana

In addition to these schemes, GoTN has been implementing the following schemes for alleviating rural poverty:

- Thanniraivu Thittam - The focus of this scheme is to create durable assets, involving the people into development process through adoption of participatory approach. It aims to promote community participation in planning, execution of development works and maintenance of community assets with 25:75 cost sharing.

- Village Fair Development Scheme - This scheme involves construction of village-fairs and creates facilities such as stalls, drinking water, public convenience, lighting etc.

- MLA/MP Constituency Local Area Development Schemes

- Integrated Rural Sanitary Complex for women

- A special project for poor weaver families in 13 districts, covering design development, skill up gradation, technology up gradation, value addition and market promotion in handloom weaving

- Special projects for the disabled persons

- RASI (Rural Access to Services through Internet) centers run by Self Help Groups

- Namadhu Gramam (our village) scheme focuses on:

$>$ Resource mapping and community mobilisation for village development

$>$ Micro planning and prioritisation of needs among Village communities (through the Gram Sabha)

$>$ Convergence of funds and functionaries of all schemes at the village level

$>$ Community led improvement in the overall quality of life.

- Empowerment and Poverty Reduction Initiative - to cover 25 ultra-poor households in every Village Panchayat annually, for a period of six years and aims at providing safety network to these households in terms of Livelihood security, Nutrition security, Shelter security and Health security.

- District Supply and Marketing Societies in all districts and Rural Bazar Website for arketing rural products.

- Multipurpose Centers for Fishermen. 


\section{MAHALIR THITTAM}

Aimed at empowering poor women, an International Fund for Agricultural Development (IFAD) funded Women Development Project was implemented in 5 districts in 1992. Encouraged by the achievement, the programme was expanded to 14 districts as Mahalir Thittam with State Govt. funding in 1996 and the coverage was extended to entire State in three phases.

The main objective of Mahalir Thittam is to empower the poor women:

- By forming community based organizations through Self Help Groups.

- By building their capacities

- By providing access to credit and other linkages

As a result of this program, around 2,61,000 women Self Help Groups have been formed benefiting about 4.30 million women members as on September 2005. A saving of Rs.8100 Million have been mobilized by the members and credit linkage of Rs.14,290 Million has been provided. In addition to the mobilization of money, this program has been successful in empowering the women socially, facilitating their participation in Gram Sabha, making them aware of government schemes, etc. However, the success achieved in social empowerment could not be capitalised significantly into economic empowerment. It could also not cover the most vulnerable sections of the community

\section{ANALYSIS AND INTERPRETATION}

Table 1: Age group of the respondents

\begin{tabular}{|l|l|l|}
\hline Age (in Year's) & Frequency & Percentage \\
\hline $21-30$ & 26 & 17.33 \\
\hline $31-40$ & 54 & 36 \\
\hline $41-50$ & 42 & 28 \\
\hline Above 50 & 28 & 18.67 \\
\hline Total & 150 & 100 \\
\hline
\end{tabular}

Source: Primary Data

Above table indicates that age group of the SHGs respondents, 36 percent of respondents are under the age of 31 to 40 years, 28 percent of respondents are under age of 41 to 50 years, 18.67 percent of respondents are above 50 years and 17.33 percent of respondents come under age of 21 to 30 years.

Table 2: Education Qualification of the respondents

\begin{tabular}{|l|l|l|}
\hline Education level & Frequency & Percentage \\
\hline School level & 41 & 27.33 \\
\hline Graduate & 58 & 38.67 \\
\hline Post Graduate & 20 & 13.33 \\
\hline Professional & 18 & 12.00 \\
\hline Others & 13 & 8.67 \\
\hline Total & 150 & 100 \\
\hline
\end{tabular}

Source: Primary Data 
From the above table clearly says that education qualification of the respondent, 38.67 percent of the respondents are qualified for under graduate level, 27.33 percent of the respondents are qualified for school level, 13.33 percent of the respondents are qualified for post graduate level, 12 percent of respondents are qualified for professional degree and 8.67 percent of respondents are qualified for other qualification.

Table 3: Gender wise respondents

\begin{tabular}{|l|l|l|}
\hline Age ( in Year's) & Frequency & Percentage \\
\hline Female & 150 & 100 \\
\hline Total & 150 & 100 \\
\hline
\end{tabular}

Source: Primary Data

Above table gender of the respondents, 100 percent of genders are female.

Table 4: Marital Status of respondents

\begin{tabular}{|l|l|l|}
\hline Marital Status & Frequency & Percentage \\
\hline Married & 116 & 77.33 \\
\hline Unmarried & 34 & 22.67 \\
\hline Total & 150 & 100 \\
\hline
\end{tabular}

Source: Primary Data

From the above table mentions that marital status of the respondents, 77.33 percent of respondents are married and 22.67 percent of the respondents are unmarried.

Table 5: Types of family

\begin{tabular}{|l|l|l|}
\hline Types of family & Frequency & Percentage \\
\hline Nuclear & 124 & 82.67 \\
\hline Joint & 26 & 17.33 \\
\hline Total & 150 & 100 \\
\hline
\end{tabular}

Source: Primary Data

From the above table clears that types of family, 82.67 percent of respondents are nuclear and 17.33 percent of respondents are joint family.

Table 6: Monthly Income of respondents

\begin{tabular}{|l|l|l|}
\hline $\begin{array}{l}\text { Monthly income } \\
\text { (in Rs) }\end{array}$ & Frequency & Percentage \\
\hline Upto 10,000 & 27 & 18.00 \\
\hline $10,000-20,000$ & 65 & 43.33 \\
\hline $20,000-30,000$ & 38 & 25.33 \\
\hline Above 50,000 & 20 & 13.34 \\
\hline Total & 150 & 100 \\
\hline
\end{tabular}

Source: Primary Data 
Above table clearly intimates that monthly income of respondents, 43.33 percent of respondents earn a monthly income of Rs.10,000 to Rs.20,000, 25.33 percent of respondents earn a monthly income of Rs.20,000 to Rs.30,000, 18 percent of respondents earn a monthly income of upto Rs.10,000 and 13.34 percent of respondents earn a monthly income of above RS.50,000.

Table 6: Monthly Saving of respondents

\begin{tabular}{|l|l|l|}
\hline Monthly Saving ( in Rs ) & Frequency & Percentage \\
\hline Below 5,000 & 43 & 28.67 \\
\hline $5,000-10,000$ & 52 & 34.66 \\
\hline $10,000-15,000$ & 37 & 24.67 \\
\hline Above 15,000 & 18 & 12.00 \\
\hline Total & 150 & 100 \\
\hline
\end{tabular}

Source: Primary Data

From the above table monthly savings of respondents, 34.66 percent of respondents monthly savings of Rs.5,000 to Rs.10,000, 28.67 percent of respondents monthly savings of below Rs.5,000, 24.67 percent of respondents monthly savings of Rs.10,000 to Rs.15,000 and 12 percent of respondents monthly savings of above Rs.15,000.

Table 7: Sources of funds

\begin{tabular}{|l|l|l|}
\hline Monthly Saving & Frequency & Percentage \\
\hline Friends & 28 & 18.67 \\
\hline Relatives & 22 & 14.67 \\
\hline Public sector Bank & 53 & 35.33 \\
\hline Private sector Bank & 33 & 22.00 \\
\hline Others & 14 & 9.33 \\
\hline Total & 150 & 100 \\
\hline
\end{tabular}

Source: Primary Data

From the above table reflects that sources of fund, 35.33 percent of the respondents sources fund from public sector banks, 22 percent of the respondents are from private sector bank, 18.67 percent of the respondents are from friends, 14.67 percent of respondents are from relatives and 9.33 percent of the respondents are from others.

\section{FINDINGS}

- Majority of respondents are under the age 31 to 40 years.

- Most of the respondents are qualified for under graduate level.

- 100 percent of genders are female.

- Maximum of respondents are married.

- Most of the respondents are nuclear.

- 43.33 percent of respondents earn a monthly income of Rs.10,000 to Rs.20,000.

- 34.66 percent of respondents monthly savings of Rs.5,000 to Rs.10,000.

- Most of the respondents sources of fund are from public sector banks. 


\section{CONCLUSION}

Among various schemes introduced by the Governments for empowering women, micro finance through self-help groups to economically backward women helped very much than any other scheme implemented by the Government so far. It also empowers women community through self-employment through micro finance. Microfinance is expected to play a significant role in poverty alleviation and rural development particularly the rural women. The potential for growing micro finance institutions in India is very high. Major cross-section can have been benefited if this sector will grow in its fastest pace.

\section{REFERENCES}

[1] http://www.yourarticlelibrary.com/india-2/self-help-group/self-help-group-shg-of-indiameaning-need-and-objectives/66718/

[2] Micro Finance through self-help groups - A survey of recent literature in India, Dr.K.Rajendran - International Journal of Marketing, Financial Services \& Management Research Vol.1 Issue 12, December 2012, ISSN 22773622.

[3] Micro Finance through Self Help Groups (SHGs): A Tool for Socio- Economic Development of Rural Assam (A Case Study of Lakhimpur and Dhemaji District) - Sri. Diganta Kumar Das, Sri. Dipul Boruah, Assam.

[4] Regi, S. B., \& Franco, C. E. (2014). ROLE OF COMMERCIAL BANK IN THE GROWTH OF MICRO AND SMALL ENTERPRISES. Golden Research Thoughts, 3 (7), 1, 5.

[5] Regi, S. B., \& Golden, S. A. R. (2014). Foreign Direct Investment-An Overview. IJARCSMS, 2 (2).

[6] Regi, S. B., (2014). Global Financial Crisis-Impact In India. Journal Of International Academic Research For Multidisciplinary, 2 (1), JIARM.

[7] Role of Self Help Groups (SHGS) in Women Empowerment - With Reference to Tamilnadu state - K.Gandhi, Dr.N.Udayakumari.

[8] www.google.com 